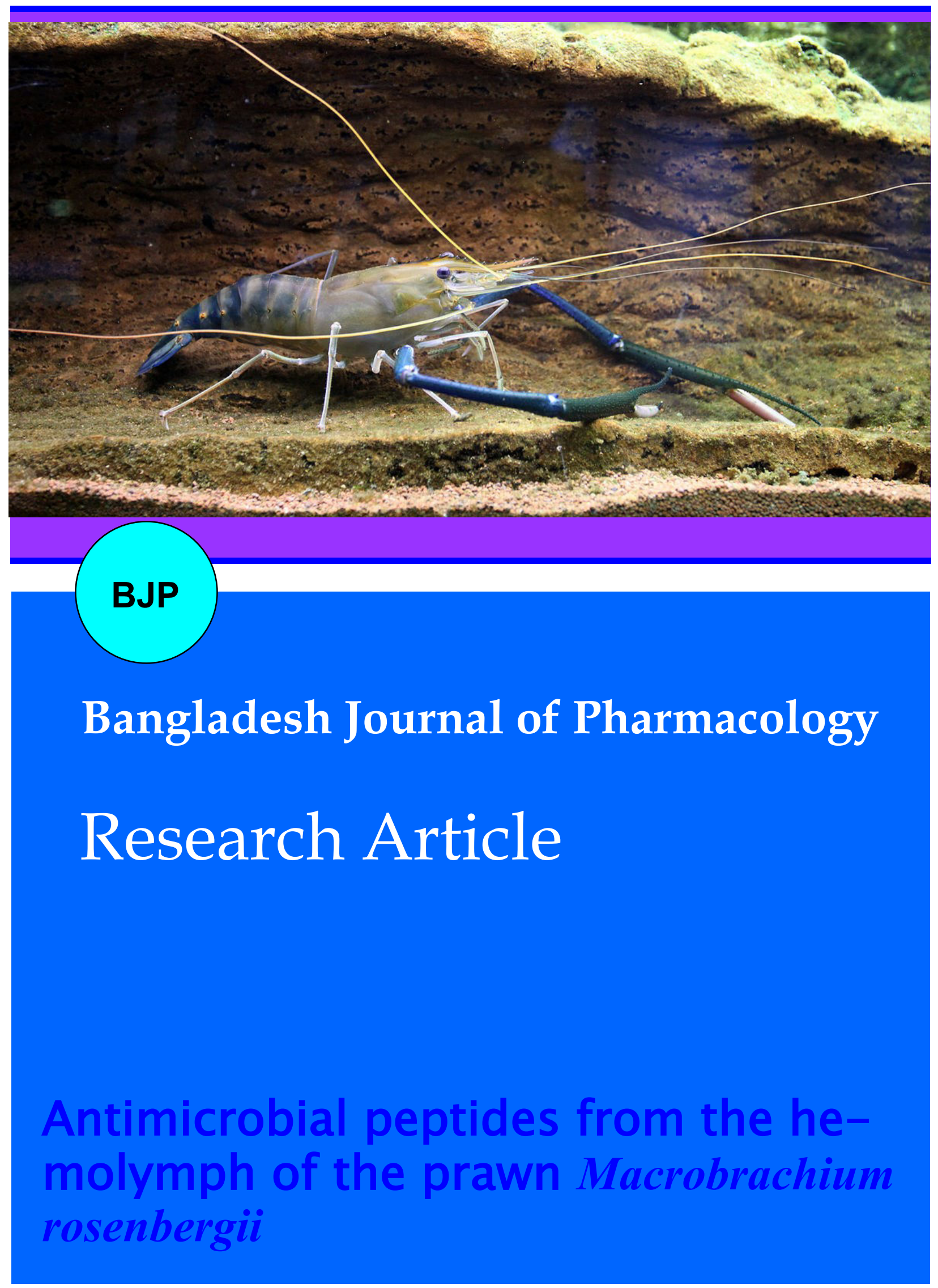


Abstracted/indexed in Academic Search Complete, Agroforestry Abstracts, Asia Journals Online, Bangladesh Journals Online, Biological Abstracts, BIOSIS Previews, CAB Abstracts, Current Abstracts, Directory of Open Access Journals, EMBASE/Excerpta Medica, Google Scholar, HINARI (WHO), International Pharmaceutical Abstracts, Open J-gate, Science Citation Index Expanded and Social Sciences Citation Index

ISSN: $1991-0088$

\title{
Antimicrobial peptides from the hemolymph of the prawn Macrobrachium rosenbergii
}

\author{
Samuthirapandian Ravichandran, Singaram Jeyalakshmi, Sathasivam Sudha and \\ Ramasamy Anbuchezhian
}

Centre of Advanced Study in Marine Biology, Annamalai University, Parangipettai 608 502, India.

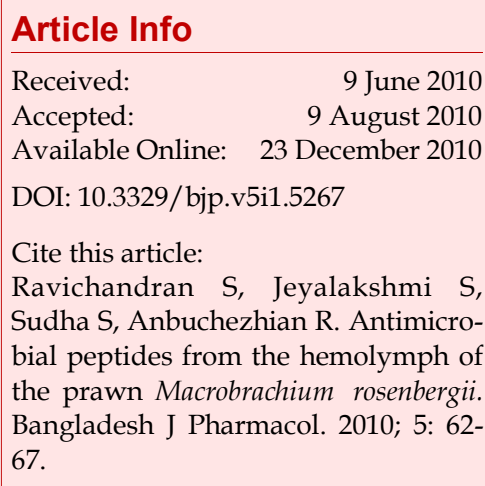

\section{Abstract}

The study was carried out to find the antimicrobial activity of hemolymph of Macrobrachium rosenbergii and to evaluate the antimicrobial compounds. The highest inhibition was observed against Staphylococcus aureus, Lactobacillus vulgaris and Klebsiella pneumoniae $(12 \mathrm{~mm})$. Antifungal activity was observed only against Fusarium moniliforme $(11 \mathrm{~mm})$. Antimicrobial peptide was characterized in molecular size ranging from 22 to $91 \mathrm{KDa}$ with antimicrobial activity against various infectious pathogens. Hemolymph plays a vital role in the disease prevention in crustaceans and there is no report on antimicrobial activities of the prawn $M$. rosenbergii.

\section{Introduction}

In crustaceans, the role of antimicrobial peptides in the survival against invading microorganisms has hardly been studied. Until now, bactericidal activities have only been demonstrated in the hemocytes of very few crustaceans (Chisholm and Smith, 1992; Ravichandran et al., 2010; Rameshkumar et al., 2009). Three constitutive hemocytic proteins have been isolated to date in the shore crab, Carcinus maenas, and one of these, a 6.5$\mathrm{kDa}$ antibacterial peptide, has been partially characterized (Schnapp et al., 1996).

Until recently, the contribution of antimicrobial peptides to crustacean defense was only suspected. Bactericidal activities were observed in Homarus americanus plasma (Stewart and Zwicker, 1972) and hepatopancreas (Mori and Stewart 1978), but were shown to be absent from the plasma of the crab C. maenas, even after microbial challenge. In crustaceans, elimination of invading organisms from the bloodstream is more likely to be mediated by hemocytes (through phagocytosis and further killing by cellular molecules) than by the presence of plasma-soluble antimicrobial factors (White at al., 1985).

As invertebrates, prawn rely upon an innate, nonadaptive immune system to live in estuarine and fresh water environments under a variety of stresses, including bacterial, fungal, and viral challenges. The innate immune response, both cellular and humoral, is very important to these organisms as a primary mechanism for protection. The production and release of antimicrobial peptides is one important mechanism to fight exposure to these microbes.

The cultivation of prawn is a worldwide economically important activity especially in intertropical developed and developing countries. However, this industry is now suffering serious problems linked to infectious diseases, which cause a decrease in growth in production resulting in vast economic losses. In this context, the control of diseases has become a priority in terms of research in immunology and genetics to insure the long term survival of shrimp aquaculture. Therefore, we have undertaken the isolation of antimicrobial peptides 
in the tropical prawn M. rosembargii.

\section{Materials and Methods \\ Animal and sample collection and preservation}

M. rosembargii specimens were collected at the Coleroon estuarine region (lat. $11^{\circ} 29^{\prime} \mathrm{N}$ and long. $79^{\circ} 50^{\prime} \mathrm{E}$ ), Southeast coast of India, and kept alive in tanks with circulating seawater. Hemolymph was collected by entering the unsclerotized membrane (Haug et al., 2002).

The plasma was first diluted $(1: 1 \mathrm{v} / \mathrm{v})$ with MilliQ water and further $(1: 1 \mathrm{v} / \mathrm{v})$ with $0.1 \%$ trifluoroacetic acid. The $\mathrm{pH}$ was then brought to 3.9 with $1 \mathrm{M}$ HCL in an ice-cold water bath under gentle stirring for 1 hour. Two successive centrifugations $\left(8,000 \times \mathrm{g}, 20 \mathrm{~min}, 4^{\circ} \mathrm{C}\right)$ were performed to clarify the supernatant, which was kept in an ice-cold water bath at $4^{\circ} \mathrm{C}$ until use.

After thawing, the hemocytes were homogenized using a Dounce apparatus (maximum, $152 \mathrm{~mm}$; minimum, 76 $\mathrm{mm}$ ) in $50 \mathrm{mM}$ Tris buffer, $\mathrm{pH} \mathrm{8.7,} \mathrm{containing} 50 \mathrm{mM}$ $\mathrm{NaCl}$. After centrifugation $\left(8,000 \times \mathrm{g}, 20 \mathrm{~min}, 4^{\circ} \mathrm{C}\right)$, the supernatant (cytosolic fraction) was acidified to $\mathrm{pH} 3.6$ by the addition of $1 \mathrm{M} \mathrm{HCl}$ and kept without freezing at $4^{\circ} \mathrm{C}$ until further purification. The pellet containing cellular organelles was extracted in $2 \mathrm{M}$ acetic acid by sonication at medium power (Branson Ultrasons, France) in an ice-cold water bath. Debris was eliminated by centrifugation $\left(8,000 \times \mathrm{g}, 20 \mathrm{~min}, 4^{\circ} \mathrm{C}\right)$, and the organelle acid extract was kept at $4^{\circ} \mathrm{C}$ until use.

\section{Microorganisms}

Antibacterial activity of brachyuran crabs hemolymph was determined against 10 bacterial strains viz., Staphylococcus aureus, Salmonella typhi, Salmonella paratyphi, Klebsiella oxytoca, Pseudomonas aeruginosa, Escherisea coli, Proteus mirabilis, Lactobacillus vulgaris, Vibrio cholerae, Vibrio harveyi, V.alginolyticus, and Klebsiella pneumoniae. The antifungal activity determined against 10 fungal strains viz., Aspergillus flavus, A. niger, A. terreus, A. fumigatus F. Moniliforme, Trichoderma sp., Penicillium citrinum, P. oxalicum, Rhizopus sp. and Trichoderma viride. These clinical strains were obtained from the Department of Medical Microbiology, Raja Muthiyah Medical College, Annamalai University, South India.

\section{Determination of antimicrobial activity}

The susceptibilities to antimicrobials were determined according to the technique of Bauer et al. (1966). Antibacterial and antifungal activity was expressed in terms of radii of zone of inhibition and was measured in mm using a scale.

\section{Antimicrobial assay}

Clinical isolates were spread plated $(200 \mu \mathrm{L})$ onto
Mueller Hinton agar No. 2 plates using a sterile spreader, taking care to distribute the microorganisms as evenly as possible over the agar surface. Hemolymph and hemocytes samples were taken in methanol and the extracts were prepared for the assay in the following manner. Sterile blanks (6 mm diameter) made of Whatman No. 1 filter paper, or prepunched (S and S Sterile blanks) were systematically laid out on a clean aluminum foil in such a manner that each extract was provided with three blanks per microorganism. Ten microliter of the extract were placed on the blanks by first applying $5 \mu \mathrm{L}$ with the pipette, allowed to evaporate, then applying another $5 \mu \mathrm{L}$, then drying again. The disc were then placed individually using a sterile forceps in appropriate grids which were marked on undersurface of the plated petri plates and kept for incubation at room temperature for 24 hours. After incubation, plates were observed for zones of inhibition that were measured with a ruler and recorded in millimeters.

\section{Protein chemistry technique}

The protein concentration of the samples was determined by the method of Lowry et al. (1951) with bovine serum albumin as standard. The basis of the method is the reaction of protein with copper under alkaline conditions and the phosphomolybdic phosphotungstic acid reduced to heteropoly molybdenum blue by the copper sulfate. The oxidation of aromatic amino acids resulting is capable of reducing molybdenum and form complex of phosphomolybdic tungstic acid.

\section{Protein separation and molecular weight determination (SDS -PAGE)}

The proteins were separated by SDS-PAGE and size of polypeptide chains of the given protein were determined by comparing its electrophoretic mobility in SDS -PAGE gel with mobility marker proteins of known molecular weight. This is used to find out the molecular weight of active fractions of the sample. SDS-PAGE was performed in $12 \%$ separating gels, according to the method described by Laemmli (1970).

\section{Thin-layer chromatography (TLC)}

As the soluble fractions showed ninhydrin positive spots they were subjected to purification by gel permeation chromatography on sephadex LH 20 using methanol as eluent and monitored by TLC. Diagnostic thin layer chromatography was performed on methanol and chloroform extracts. They were also spotted and plates developed in varying proportions. Detection was done with the specific color reagent ninhydrin, for detecting the compounds.

\section{NMR}

NMR samples were prepared by dissolving them after purification in a denatured solvent. Several deuterium 


\begin{tabular}{|c|c|c|c|c|}
\hline \multicolumn{5}{|c|}{ Table I } \\
\hline \multicolumn{5}{|c|}{ Antibacterial activity of plasma and hemocytes of $M$. rosenbergii } \\
\hline Bacterial pathogens & Male plasma & Female plasma & Male hemocytes & Female hemocytes \\
\hline Staphylococcus aureus & - & - & ++ & ++ \\
\hline Salmonella typhi & - & - & + & + \\
\hline Salmonella paratyphi & - & - & - & + \\
\hline Klebsiella oxytoca & - & - & ++ & + \\
\hline Pseudomonas aeruginosa & - & - & ++ & ++ \\
\hline Escherisea coli & - & - & ++ & ++ \\
\hline Proteus mirabilis & - & - & ++ & ++ \\
\hline Lactobacillus vulgaris & - & - & ++ & ++ \\
\hline Vibrio cholerae & - & - & ++ & ++ \\
\hline Klebsiella pneumoniae & - & - & ++ & ++ \\
\hline Vibrio harveyi & - & - & ++ & ++ \\
\hline Vibrio alginolyticus & - & - & ++ & ++ \\
\hline
\end{tabular}

lock solvents are available like $\mathrm{CDCl} 3, \mathrm{CD} 3 \mathrm{OD}$ and D2O. NMR spectroscopy can provide a wealth of additional information about peptide in solution.

\section{Results}

In the present study plasma and the hemocytes of both male and female samples were separated. After centrifugation hemocytes were separated and sonicated to get the contents present inside the cells. Plasma, the haemocyte separated hemolymph was also analysed for antimicrobial activity. Surprisingly plasma did not show any microbial activity.

All the bacterial pathogens tested were susceptible to hemocytes. Antimicrobial activities of male and female hemocytes were investigated against the pathogenic strains. In male hemocytes, maximum activity was shown against E. coli, L. vulgaris, Vibrio cholerae and $K$. pneumonia, $V$. harveyi, $V$. alginolycus $(12 \mathrm{~mm})$ and Salmonella paratyphi showed total resistance (no zone). The female hemocytes shown maximum activity (12 $\mathrm{mm})$ against $S$. aureus, L. vulgaris, K. pneumonia, $V$. harveyi, $V$. alginolycus. Both male and female hemocyte samples shown minimum $(9 \mathrm{~mm})$ activity against Salmonella typhi (Table I).

When compared to bacterial pathogens, fungal pathogens showed more resistance to the tested hemocyte samples. The hemocytes of male crab had not shown any antifungal activity against the tested strains. Only Fusarium moniliforme (11 $\mathrm{mm}$ ) and Penicillium citrinum (9 $\mathrm{mm}$ ) have shown inhibition towards female hemocyte samples.
Protein estimation in cell free hemolymph and hemocytes showed remarkable variations. The protein content of cell free hemolymph was $0.3 \mathrm{mg} / \mathrm{mL}$ (male) and $0.2 \mathrm{mg} / \mathrm{mL}$ (female). Moreover female hemocyte had higher protein content $(0.9 \mathrm{mg} / \mathrm{mL})$ compared to that of males $(0.6 \mathrm{mg} / \mathrm{mL})$.

The hemolymph sample was subjected to SDS polyacrylamide gel electrophoresis to estimate the molecular weight of proteins in it. Different standard were used to determine the molecular weight of biologically active proteins. SDS-PAGE of hemocyte contents showed many protein bands with molecular size ranging from 22 to $91 \mathrm{KDa}$ (Figure 1).

The hemolymph showed antimicrobial activity was subjected to purification by gel filtration chromatography, TLC and NMR studies. After spotting the fraction on TLC plate and spraying with ninhydrin, pink spots was observed. As it is well known that peptides are known to yield pink spots with ninhydrin and since it had yielded pink spots it was taken up for further investigation leading to the isolation of peptides. Hence, the chromatographed first on sephadex LH20 followed by final purification on silica gel. Different fractions eluted from the column were mixed on the basis of same Rf values.

The same Rf value fractions of TLC samples were separated by column chromatography over sephadex LH20. They were mixed together and subjected to NMR analysis. Ninhydrin positive spots indicating the possibility of containing peptides, further confirmed by the presence of doublets in the region of 8 6-8 in its ${ }^{1} \mathrm{HNMR}$ spectrum (Figure 2). Based on the investigation 


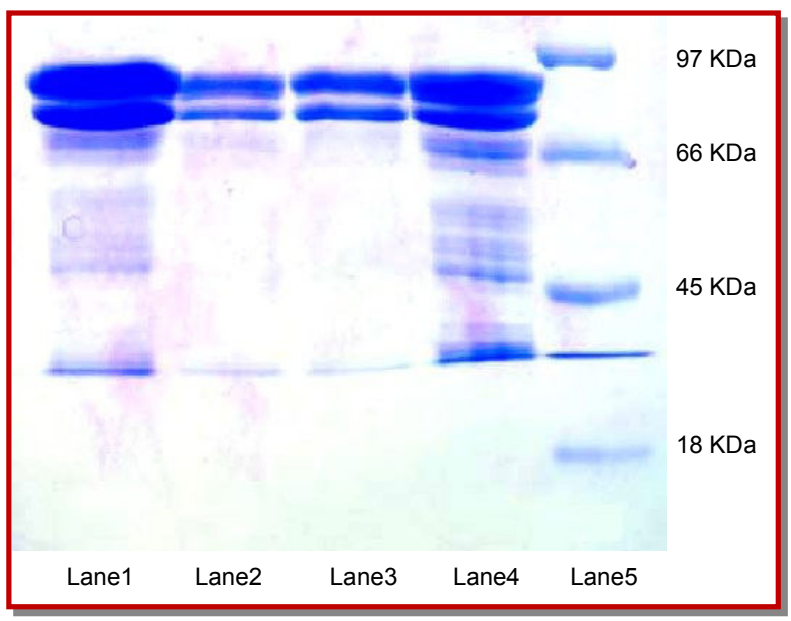

Figure 1: SDS-PAGE profile (Lane 1: Male hemocytes; Lane 2: Male plasma; Lane 3: Female plasma; Lane 4: Female hemocytes; Lane 5: Protein marker)

of TLC, SDS-PAGE and NMR studies showed ninhydrin positive spots indicating the presence of peptides.

\section{Discussion}

This study has described the isolation of antimicrobial peptides from the hemolymph and hemocytes of the both male and female river prawn $M$. rosenbargii.

Antibacterial and antifungal activities for both male and female samples were tested in which the sonicated contents of hemocyte samples have showed significant activity. The antimicrobial peptides are highly conserved between species. Our results indicate that hemocytes in $M$. rosenbargii have antimicrobial activity in vitro. The protein content of cell free hemolymph and hemocytes showed different magnitude. Hemocyte samples showed maximum protein content than the cell free hemolymph and compare with male hemocytes female hemocytes showed the maximum values.

Surprisingly Salmonella paratyphi showed total resistance (no zone). The resistance of $S$. paratyphi needs further research to confirm the mechanism involved. The result confirmed that as males and females are in the same environment they might be exposed to similar kind of pathogens. According to Destoumieux et al. (1999) the penaeidins had no effect on gram-negative bacteria such as the Vibrio sp. Munoz et al. (2004) reported that penaeidins from the shrimp Litopenaeus stylirostris showed activity against a pathogenic Vibrio penaeicida.

Hemocytes showed lesser inhibitory to fungal

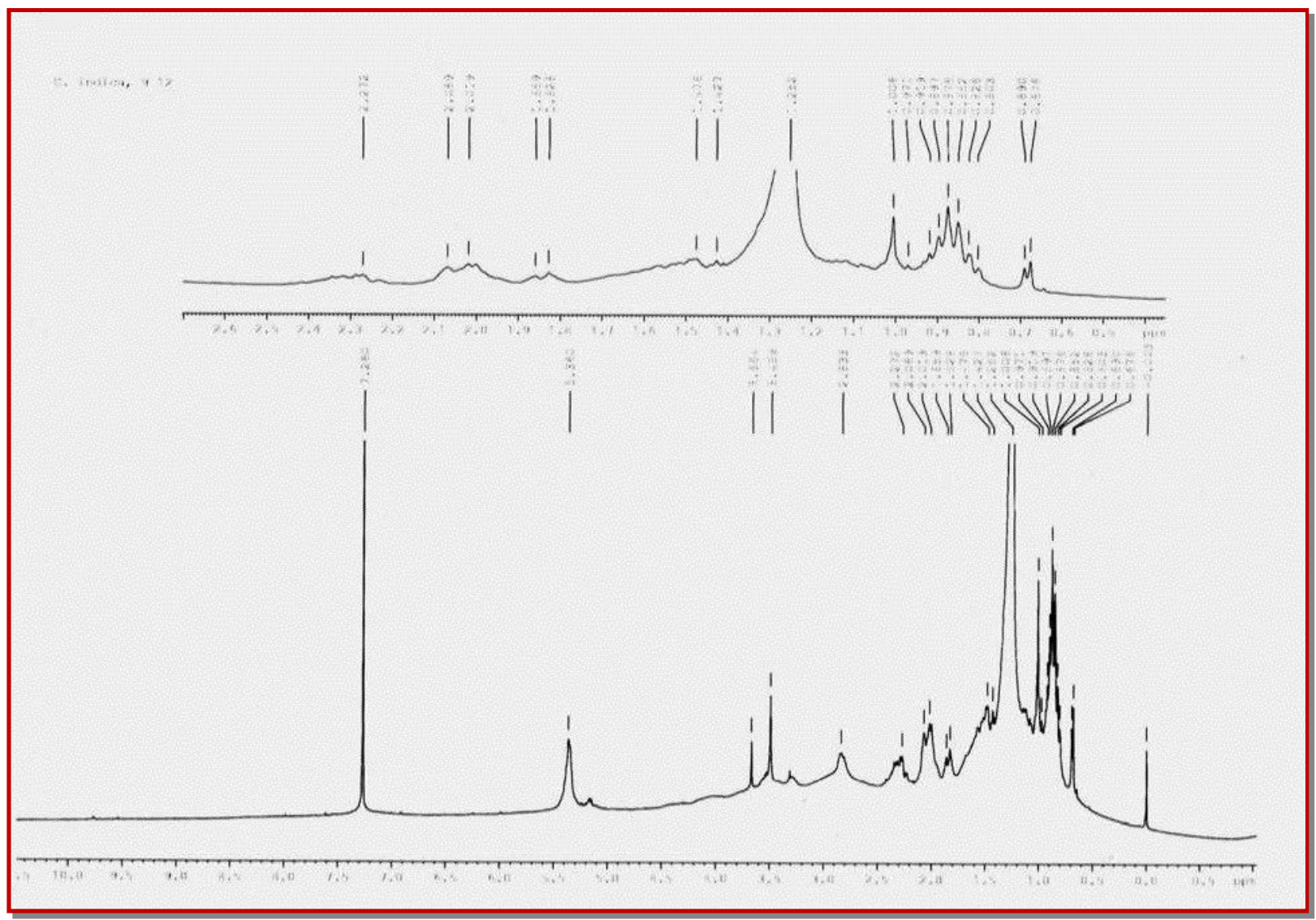

Figure 2: The 1H NMR spectrum of peptides in M. rosenbergii 
pathogens compared to bacterial pathogens. Destoumieux et al. (1999) reported the antifungal activities of Penaeus stylirostris against F. oxysporum. Cuthbertson et al. (2006) have reported activities of Penaeidins against pathogenic fungi of the phylum Basidiomycota (Cryptococcus and Candida sp.). Kawabata et al. (1996) opined that, penaeidin chitin-binding ability may be responsible for their antifungal activity, as suggested for the horseshoe crab tachycitin. However, in the present study male and female plasma did not inhibit fungi which deserve further research.

Destoumieux et al. (1997) reported that shrimp plasma contains an original class of strictly antifungal (poly) peptides with molecular masses ranging from 2753.2 Da for the peptide originating from P. vannamei to 7982.4 and 8362.8 Da for the molecules found in P. stylirostris. Pan et al. (2008) reported two bands at molecular weight around 73 and $75 \mathrm{KDa}$ from hemocyte samples of L. vannamei. In the present study, molecular size of bands at ranging from 22 to $91 \mathrm{KDa}$ was noticed.

Penaeidins are a family of antimicrobial peptides of 4774 amino acids isolated originally from the hemolymph of the shrimp Penaeus vannamei (Pacific white shrimp) (Destoumieux et al., 1997), black tiger shrimp (Penaeus monodon) (Supungul et al., 2002; Chiou et al., 2007), and are found also in L. vannamei, L. setiferus (Atlantic white shrimp) (Cuthbertson et al., 2002) and L. stylirostris (blue shrimp).

The immune system of this differs from that described in insects, where the fat body is the main site for the antimicrobial peptide synthesis (Hoffmann and Reichhart, 1997; Engstrom, 1998), and upon injury antimicrobial peptide gene transcription is induced, resulting in their immediate synthesis and subsequent secretion into the blood. Secondary expression sites such as gonads or intestine (Ferrandon et al., 1997) were also found in insects, where different pathways regulate gene expression.

The present study also revealed that the hemocytes might be the site of production and storage for these antimicrobial peptides. As the $M$. rosenbergii tested in the present study are healthy individuals, plasma may not have shown any antimicrobial activity. As suggested by other researchers their presence in the plasma might indicate immune response stimulation by exposure to pathogens. Decapod hemocytes are known to contain several immune effectors and they play a major role in the cellular and humoral defense mechanisms of the host (Smith and Soderhall, 1983). It is believed that circulating hemocytes are playing an important role in the innate immune system of invertebrates, including being the storage reservoir of several immune components, such as lectins, coagulation factors, protease inhibitors, pro- PO activation components, and AMPs (Iwanaga, 2002; Soderhall and Cerenius, 1998).
From the present study hemolymph of $M$. rosenbergii antimicrobial peptide was characterized in molecular size ranging from 22 to $91 \mathrm{KDa}$. Further structureactivity-related studies would give information regarding the importance of different amino acid residues of the peptide for the antimicrobial activity and the mechanisms of actions involved.

\section{Acknowledgement}

Authors are very much thankful to Dr. T. Balasubramanian, Centre of Advanced Study in Marine Biology and authorities of Annamalai University for their outrageous encouragement and facilities provided throughout the research work.

\section{References}

Bartlett TC, Cuthbertson BJ, Shepard E, Chapman R, Gross P, Warr G. Crustins, homologues of an $11.5-\mathrm{kDa}$ antibacterial peptide, from two species of penaeid shrimp, Litopenaeus vannamei and Litopenaeus setiferus. Mar Biotechnol. 2002; 4: 278-93.

Bauer AW, Kirby WMM, Sherris JC, Turck M. Antibiotic susceptibility testing by a standardized single disc method. Am J Clin Pathol. 1966; 45: 493-96.

Chiou $\mathrm{T}$, Jen-Leih $\mathrm{Wu}$, Thomas $\mathrm{T}$, Chen $\mathrm{L}$, Jenn-Kan Lu. Molecular cloning and characterization of cDNA of penaeidine: Antimicrobial peptide from tiger shrimp (Penaeus monodon). Marine Biotechnol. 2007; 204: 1013-20.

Chisholm JRS, Smith VJ. Antibacterial activity in hemocytes of the shore crab, Carcinus maenas (L). J Mar Biol Assoc UK. 1992; 72: 529-42.

Cuthbertson BJ, Bullesbach EE, Gross PS. Discovery of synthetic penaeidin activity against antibiotic-resistant fungi. Chem Biol Drug Des. 2006; 68: 120-27.

Cuthbertson BJ, Shepard EF, Chapman RW, Gross PS. Diversity of the penaeidin antimicrobial peptides in two shrimp species. Immunogenetics 2002; 54: 442-45.

Destoumieux D, Bulet P, Loew D, Dorsselaer AV, Rodriguez J, Bachere E. Penaeidins, a new family of antimicrobial peptides isolated from the shrimp Penaeus vannamei (Decapoda). J Biol Chem. 1997; 272: 28398-406.

Destoumieux D, Bulet P, Strub JM, Dorsselaer AV, Bachere E. Recombinant expression and range of activity of penaeidins, antimicrobial peptides from penaeid shrimp. Eur J Biochem. 1999; 266: 335-46.

Destoumieux D, Saulnier D, Garnier J, Jouffrey C, Bulet P, Bachere E. Crustacean immunity: Antifungal peptides are generated from the $C$ terminus of shrimp hemocyanin in response to microbial challenge. J Biol Chem. 1999; 276: 47070-77.

Engstrom Y. Insect immune gene regulation. In: Molecular mechanisms of immune response in insects. Brey PT, Hultmark D (eds). London, Chapman and Hall Publishers, 1999, pp 211-44. 
Ferrandon D, Jung AC, Criqui MC, Lemaitre B, UttenweilerJoseph S, Michaut L, Reichhart J, Hoffmann JA. A drosomycin- GFP reporter transgene reveals a local immune response in Drosophila that is not dependent on the Toll pathway. EMBOJ. 1998; 17: 1217-27.

Haug T, Kjuul AK, Stensvag K, Sandsdalen E, Styrvold OB. Antibacterial activity in four marine crustacean decapods. Fish Shellfish Immunol. 2002; 12: 371-85.

Hoffmann JA, Reichhart JM. Drosophila immunity. Trends Cell Biol. 1997; 7: 309-316.

Iwanaga, S. The molecular basis of innate immunity in the horseshoe crab. Curr Opin Immunol. 2002; 14: 87-95.

Kawabata SI, Nagayama R, Hirata M, Shigenaga T, Agarwala KL, Saito T, Cho J, Nakajima H, Takagi T, Iwanaga S. Tachycitin, a small granular component in horseshoe crab hemocytes is an antimicrobial protein with chitin-binding activity. J Biochem. 1996; 120: 1253-60. PMid:9010778

Laemmli UK. Cleavage of structural proteins during the assembly of the head of bacteriophage T. Nature 1970; 227; 680-85.

Lowry OH, Rosenbrough JN, Farr AL, Randall RJ. Protein measurement with folin-phenol reagent. J Biol Chem. 1951; 193: 265-75. PMid:14907713

Mori K, Stewart JE. The hemolymph bactericidin of the american lobster (Homarus americanus) adsorption and activation. J Fish Res Board Canada. 1978; 5: 1504-07.

Munoz M, Vandenbulcke F, Garnier J, Gueguen Y, Bulet P, Saulnier D, Bachere E. Involvement of penaeidins in defense reactions of the shrimp Litopenaeus stylirostris to a pathogenic Vibrio. Cell Mol Life Sci. 2004; 61: 961-72.

Pan JY, Zhang YL, Peng XX. Dodecamer is required for agglutination of Litopenaeus vannamei hemocyanin with bacterial cells and red blood Cells. Mar Biotechnol. 2008; 301: 39-54.

Rameshkumar G, Ravichandran S, Kaliyavarathan G, Ajithkumar TT. Antimicrobial peptide from the crab, Thalamita crenata (Latreille, 1829). World J Fish Marine Sci. 2009; 1: 7479.

Ravichandran S, Wahidulla S, D'Souza L, Rameshkumar G. Antimicrobial lipids from the lemolymph of brachyuran crabs. Appl Biochem Biotechnol. 2010; 162: 1039-51.

Schnapp D, Kemp GD, Smith VJ. Purification and characterization of a proline- rich antibacterial peptide, with sequence similarity to bactenecin-7, from the hemocytes of the shore crab, Carcinus maenas. Eurobian J Biochem. 1996; 240: 532-39.

Smith VJ, Soderhall K. p-1,3-Glucan activation of crustacean hemocytes in vitro and in vivo. Biol Bull. 1983; 164: 299-314.

Soderhall K, Cerenius L. Role of the prophenoloxidaseactivating system in invertebrate immunity. Curr Opin Immunol. 1998; 10: 23-28.

Stewart JE, Zwicker BM. Natural and induced bactericidal activities in the hemolymph of the lobster, Homarus americanus: Products of hemocyte-plasma interaction. Can J Microbiol. 1972; 18: 1499-509.

Supungul P, Klinbunga S, Pichyangkura R, Jitrapakdee S, Hirono I, Aoki T, Tassanakajon A. Identification of immunerelated genes in hemocytes of black tiger shrimp (Penaeus monodon). Mar Biotechnol. 2002; 35: 4487-94.

White KN, Ratcliffe NA, Rossa M. The antibacterial activity of haemocyte clumps in the gills of the shore crab, Carcinus maenas. J Mar Biol Assoc UK. 1985; 65: 857-70. 